\title{
STRATEGI SELLING-IN, HUBUNGAN DISTRIBUTOR DENGAN OUTLET, DAN STRATEGI PELAYANAN OUTLET PENGARUHNYA TERHADAP KINERJA PEMASARAN
}

\section{SELLING-IN STRATEGY, DISTRIBUTOR RELATIONSHIPS WITH OUTLETS, AND OUTLET SERVICE STRATEGIES THE EFFECT ON MARKETING PERFORMANCE}

\author{
Slamet Wijiono, Dwi Cahyono, Nurul Qomariah \\ Program Magister Majajemen Pascasarjana Universitas Muhammadiyah Jember \\ Email: slametwijiono@unmuhjember.ac.id, dwicahyono@unmuhjember.ac.id, \\ nurulqomariah@unmuhjember.ac.id
}

\begin{abstract}
ABSTRAK
Strategi Selling-In, hubungan distributor dengan outlet, dan strategi pelayanan outlet merupakan suatu kegiatan yang harus dilakukan oleh perusahaan dewasa ini untuk menjamin efektifitas kegiatan marketing sehingga produk secara optimal dengan perantara outlet untuk menjangkau konsumen akhir.Hal ini akan menjadi indicator bahwa kinerja pemasaran dapat dikatakan berjalan dengan baik. Dalam Kinerja Pemasaran yang baik ada tiga faktor utama yang menjadi besaran nilai yaitu volume penjualan, pertumbuhan dan penjualan serta porsi pasar. Tiga faktor tersebut sangat mungkin berjalan seiring jika ada follow up yang rutin dan terus menerus oleh perusahaan di tingkat outlet rekanan, hal ini akan menjamin ketersediaan barang dan memastikan konsumen akhir untuk mendapatkan barang yang diinginkan.Sehingga kepuasan konsumen akan tercapai dan bagi perusahaan akan dapat meningkatkan penjualan. Terbukti bahwa strategi selling-in, hubungan distributor dengan outlet, dan strategi pelayanan outlet berpengaruh significant terhadap kinerja pemasaran.
\end{abstract}

Kata Kunci : Selling-In, Kinerja Pemasaran, Outlet

\begin{abstract}
Strategy of Selling-In, distributor relation/link with outlet, and strategy service of outlet represent an activity which must be done/conducted by company these days to guarantee efektifitas activity of marketing so that product in an optimal fashion with medium of outlet to reach consumer of akhir.Hal this will become indicator that marketing performance can be told to walk better. In good Performance Marketing there is three primary factor becoming value assess that is 1) Volume Sale 2) Growth of Sale 3) Portions the Market. Three a factor very possible walk along if there is continuous and routine up follow by company in storey; level of outlet client, this matter will guarantee the availibility of goods and ascertain final consumer to get goods which is wants.So that satisfaction of consumer will reach and to company will be able to improve sale. Proven that strategy of selling-in, distributor relation with outlet, and strategy service of outlet have an effect on significant to marketing performance.
\end{abstract}

Keyword : Selling-In, Performance Marketing, Outlet

\section{PENDAHULUAN}

Seiring dengan pertumbuhan dan perkembangan perekonomian yang semakin pesat, yang diikuti oleh dinamika dalam proses menuju sebuah tatanan yang semakin maju, mengakibatkan berbagai ragam permasalahan yang perlu dipecahkan, diantaranya 
turunya volume penjualan dan turunya pertumbuhan penjualan.Kondisi seperti ini sangat terasa dalam berbagai bidang usaha, baik yang bergerak di bidang jasa, perdagangan, maupun industri. Dengan menggunakan fasilitas yang tersedia, perusahaan yang berskala besar maupun kecil dapat dipastikan telah mempunyai tujuan yang telah direncanakan, yang pada umumnya untuk menciptakan keuntungan demi kelangsungan hidup perusahaan dan kepuasan semua pihak atau kesejahteraan karyawan. Hal ini menimbulkan tuntutan tanggung jawab yang besar dari pihak manajemen perusahaan terhadap pelaksanaan kegiatan perusahaan secara menyeluruh, karena keberhasilan perusahaan dalam merealisasikan tujuan pada umumnya di tandai oleh kemampuan pimpinan perusahaan dan jajaranya dalam menghadapi berbagai kemungkinan yang akan terjadi pada masa yang akan datang. Dalam era globalisasi yang ada saat ini menyebabkan persaingan dalam dunia bisnis menjadi semakin ketat.Perusahaan harus selalu meningkatkan kemampuanya agar dapat bertahan dan memenangkan persaingan dalam perubahan lingkungan bisnis yang semakin ketat.

Tingkat persaingan yang sangat ketat dan ditandai oleh menurunya volume penjualan perusahaan, menyebabkan seluruh masyarakat dunia pelaku usaha di era globalisasi yang ingin tetap mempertahankan eksistensinya harus memobilisasi seluruh potensi dengan kekuatan yang dimilikinya agar dapat bersaing. Kondisi di atas mengharuskan perusahaan untuk dapat mengatasi iklim persaingan pasar dan sekaligus untuk mendapatkan profit yang besar melalui peningkatan pertumbuhan volume penjualan.

Sehinggga setiap perusahaan dewasa ini dituntut untuk lebih mengenal pasar sebaik mungkin agar dapat sukses dalam persaingan. Karena persaingan dapat digambarkan sebagai sebuah system hubungan (system of relationship) dimana pemasar hanya dapat eksis dan bertahan bila mereka mempunyai keunggulan keunggulan unik (unique advantages) dibandingkan dengan lawanya (Hendersen, 1983). Jika mereka tidak mempunyai keunggulan unik, maka pesaingnya dapat menggeser posisi strategisnya, dan karena itu semakin mirip profil strategic sebuah perusahaan dibandingkan dengan pesaing terdekatnya, maka semakin keras persaingan pasar terjadi. Dan dalam persaingan yang keras tersebut perusahaan dapat mengembangkan keunggulan keunggulan uniknya melalui produk, harga, promosi, dan distribusi, melalui cara tersebut posisi pasar dapat dipertahankan bahkan dapat ditingkatkan. 
Strategi distribusi adalah salah satu bidang strategi pemasaran yang ditujukan terutama untuk meningkatkan penjualan serta porsi pasar untuk menunjang pertumbuhan berkelanjutan. Sebagai sebuah instrument strategi, kebijakan distribusi dapat digunakan untuk memanajemeni persaingan, di bawah asumsi bahwa semakin tinggi intensitas distribusi diterapkan akan semakin kokoh kekuatan yang dimiliki dan semakin besar kemungkinan bahwa produk yang di tawarkan dapat dijual pada pasar target tertentu. Secara teoritis perusahaan dapat mengembangkan strategi distribusinya berdasarkan pada sifat produk serta kekuatan yang mereka miliki atau kekuatan yang mereka dapat dalam mekanisme operasi pasar.

Saat ini produsen berlomba lomba mengalihkan fungsi penjualan langsung produk mereka kepada outlet dengan alasan ekonomis dan keunggulan dalam jangkauan penyebaran produk distributor pada target pelanggan atau konsumen, hasil produksi tidak bisa dijual jika perusahaan tidak mempunyai saluran distribusi yang baik.Sehingga distribusi merupakan hal yang penting dan perlu untuk diteliti mengenai hal hal apa saja yang dapat membuat distribusi berhasil. Penekanan pada hubungan antara produsen dan outlet merupakan langkah strategis yang menguntungkan bagi kedua belah pihak (produsen dan outlet). Hubungan produsen dan outlet potensial merupakan pilihan strategi yang tepat dan terarah manakala beban dan tugas serta fungsi outlet yaitu menyalurkan atau mendistribusikan produk yang dihasilkan produsen kepada konsumen.

Salah satu jenis industri yang semakin ketat dalam persaingan adalah industri consumer goods khusunya minuman sari buah. Sehingga dalam penelitian ini, objek penelitian yang dipilih ialah pada CV Rajeev Indo Soul Elmo (RISE) Kabupaten Malang. Pesatnya perkembangan jaman banyak mengubah prilaku konsumen dalam memilih produk karena banyaknya pilihan produk di pasar. Konsumen dihadapkan pada banyak pilihan dalam memenuhi selera dan rasa. Dengan semakin beragamnya jenis produk yang ditawarkan memberi peluang kepada konsumen untuk membeli produk yang sesuai dengan keinginanya. Tetapi dengan perkembangan yang demikian itu dirasakan sebagai sebuah tantangan bagi para pelaku bisnis. Mereka tidak lagi berdiam diri dalam menjalankan bisnisnya yang menuntut adanya kreatifitas dengan perencanaan dan perhitungan yang matang untuk menghadapi dinamika dan tantangan bisnis yang ada. Karena dengan semakin bertambahnya pelaku bisnis dalam industry dapat berarti bertambahnya pesaing (competitor). 


\section{TINJAUAN PUSTAKA}

\section{Kinerja Pemasaran}

Pemasaran merupakan suatu proses manajerial dimana individu dan kelompok mendapatkan kebutuhan dan keinginan mereka dengan menciptakan, menawarkan dan bertukar sesuatu yang bernilai satu sama lain ( Qomariah, 2016). Menurut Ferdinand (2004) kinerja pemasaran adalah sebuah pencapaian yang dihasilkan oleh dampak dari berbagai peran yang ada di dalam organisasi, .salah satu strategi yang dimainkan oleh perusahaan adalah mengembangkan strategi Selling- In sebagai upaya membangun akses pasar bagi produk yang masuk dalam pasar yang tersebar dan kompetitif.

Kinerja pemasaran merupakan faktor yang seringkali digunakan untuk mengukur dampak dari strategi yang diterapkan perusahaan. Strategi perusahaan pada umumnya selalu diarahkan untuk menghasilkan kinerja pemasaran yang unggul. Walaupun tidak ada kepastian tentang dimensi kinerja pemasaran, namun pada umumnya dimensi yang dipakai untuk mengukur kinerja pemasaran meliputi pertumbuhan penjualan, pertumbuhan pelanggan, dan volume penjualan sebagai alat pengukuran kinerja pemasaran perusahaan. Sedangkan Ferdinand (2000) menyatakan bahwa kinerja pemasaran yang baik dinyatakan dalam tiga besaran utama nilai, yaitu : penjualan, pertumbuhan penjualan, pertumbuhan pelanggan. Ketiga besaran utama nilai tersebut bermuara pada keuntungan penjualan perusahaan yang menunjukkan berapa rupiah atau berapa unit produk yang terjual, sedangkan pertumbuhan penjualan menunjukkan berapa besar kenaikan penjualan produk yang sama dibandingkan satuan waktu tertentu. Pertumbuhan pelanggan menunjukkan seberapa besar kontribusi produk yang ditangani menguasai pelanggan pada produk sejenis dibanding para competitor (market share). Hubungan antara kinerja selling-in dengan kinerja pemasaran dapat dijelaskan sebagai berikut : Kinerja pemasaran yang salah satu dimensinya adalah pertumbuhan penjualan dapat dicapai dengan cara memasarkan produk sebanyak banyaknya.

\section{Kinerja Selling-In}

Menurut Lindsay dan Maureen (2001) Selling-In merupakan sebuah konsep penjualan yang menitik beratkan pada penjualan yang dilakukan oleh distributor kepada pelangganya, seperti subdistributor, grosir, dan retailer. Konsep penjualan ini membatasi penjualan hanya pada mata rantai saluran distribusi, tidak sampai ke pembeli akhir.

Sasaran kegiatan selling-In adalah teradinya transaksi intermediaris yaitu 
diterimanya produk oleh pelanggan untuk dipajang di outlet pelanggan dan di jual pada konsumen akhir (Augusty,2004). Pengelolaan proses selling-in itu sendiri dapat digambarkan sebagai sebuah rantai nilai proses untuk menciptakan pelanggan dan menghasilkan return bagi perusahaan.

\section{Hubungan Distributor Dengan Outlet}

Pada kontek saluran distribusi, penelitian telah menunjukan bahwa saluran distribusi ke bawah yang percaya kepada pemasoknya menunjukan tingkat coopratif yang lebih tinggi dan melakukan effort yang lebih bagi kepentingan principal (Morgan and Hunt 1994).Kepercayaan kepada pemasok juga dapat mengurangi konflik dan mempererat kepuasan saluran distribusi. Hubungan (Relationship dipandang sebagai factor yang sangat penting, beberapa penelitian membuktikan hal tersebut diantaranya adalah Dwyer,Schurr, dan OH (dalam Donney dan Cannon,1997) menyatakan bahwa membangun hubungan yang baik dengan pelanggan merupakan responsibilitas perusahaan agar dapat bertahan dalam persaingan.Ganesan (dalam Doney dan Cannon, 1997) memandang Relationship berfungsi sebagai alat untuk mempertahankan kompetisi dan mengurangi biaya transaksi.

\section{Strategi Pelayanan Outlet}

Strategi pelayanan outlet merupakan salah satu penentu keberhasilan penjualan. Yang dimaksud strategi pelayanan outlet adalah keputusan manajemen yang menjawab pertanyaan bagaimana outlet itu dikelola guna mendatangkan manfaat yang paling optimal bagi perusahaan. Semakin baik penanganan outlet maka semakin efektif pula perusahaan dapat menjual produknya (Sunaryo,2001). Efektifitas keputusan manajemen atas pelayanan outlet akan sangat tergantung dari ketepatan kunjungan (call) penjualan yang tercipta, dan system pembayaran penjualan (Term Of Payment) yang tepat, serta kebijakan retur yang dipakai. Dalam Ferdinand (2004), Adrian B Ryans dan Charles B Wenberg (1977) merupakan strategi pelayanan outlet sebagai Territory Sales Respons yang berpengaruh terhadap kinerja penjualan (Selling-In). Sedangkan Craven,Woodroff, dan Stamper (1972) mengevaluasi kinerja pada wilayah penjualan.

\section{Outlet}

Outlet berarti toko atau tempat penjualan, kata outlet mengandung pengertian bahwa toko atau tempat penjualan itu hanya menjual barang-barang yang merupakan satu produk tertentu. Kata outlet masih sering dipakai karena padananya dalam bahasa 
Indonesia belum ada, dalam hal ini kata outlet bisa diartikan toko. Seringkali istilah Outlet tidak dapat dipisahkan dengan kata counter dan gerai, kata counter berarti toonbank, meja pajangan atau kedai, kasir. Kata tersebut mengandung pengertian bahwa counter bukanlah toko, tetapi meja atau kedai kecil tempat menjual barang barang, misalnya counter kosmetik, obat obatan atau majalah. Kata gerai berarti kedai kecil, meja tempat menjual barang. Kata gerai ini mengandung pengertian bahwa gerai bukanlah toko, tetapi meja atau kedai kecil tempat menjual barang-barang. Jadi di dalam toko bisa terdapat beberapa gerai.

Berdasarkan pengertian outlet, counter dan gerai tersebut, kata gerai merupakan padanan bahasa Indonesia dari kata counter. Jadi penggunaaan kata yang benar untuk kedai atau meja kecil tempat menjual barang-barang adalah gerai, bukan counter, karena kata counter masih merupakan kata asing/inggris.

\section{METODE PENELITIAN}

\section{Populasi dan Sampel}

Populasi adalah wilayah generalisasi yang terdiri atas objek atau subjek yang mempunyai kualitas dan karakteristik tertentu yang telah ditetapkan oleh peneliti untuk dipelajari dan kemudian ditarik kesimpulannya (Sugiyono, 2002).Ada pula yang menyatakan bahwa populasi adalah gabungan dari seluruh elemen yang berbentuk peristiwa, hal atau orang yang memiliki karakteristik yang serupa yang menjadi pusat perhatian seorang peneliti (Ferdinand, 2006). Populasi dalam penelitian ini adalah outlet CV.Rajeev Indo Soul Elmo di area Kabupaten Malang yang berjumlah 206 outlet. Sampel adalah bagian yang dapat mewakili populasi yang memiliki karakteristik yang sama dan dianggap bisa mewakili populasi (Sugiyono, 2002). Sampel dalam penelitian ini adalah outlet CV.Rajeev Indo Soul Elmo Kabupaten Malang. Namun yang perlu diperhatikan adalah semakin besar jumlah sampel (semakin mendekati populasi) maka semakin kecil peluang kesalahan generalisasi dan sebaliknya, semakin kecil jumlah sampel (menjauhi jumlah populasi) maka semakin besar peluang kesalahan generalisasi. Mengacu pada pendapat diatas dan berdasarkan pertimbangan yang telah dikemukakan, maka jumlah sampel yang di gunakan dalam penelitian ini sebanyak 100 reponden, pengambilan sampel yang digunakan dalam penelitian ini adalah Non probability sampling yaitu metode purposive sampling. Purposive sampling. 


\section{Uji Validitas}

Validitas didefinisikan sebagai ukuran seberapa kuat suatu alat tes melakukan fungsi ukurannya. Model pengujian menggunakan pendekatan Pearson Correlation untuk menguji validitas pernyataan kuesioner. Uji validitas digunakan untuk mengukur sah atau tidaknya suatu kuesioner.

\section{Uji Reliabilitas}

Apabila validitas telah diperoleh, maka peneliti harus mempertimbangkan pula pengukuran reliabilitas. Reliabilitas menunjukkan pada satu pengertian bahwa suatu instrumen cukup dapat dipercaya untuk digunakan sebagai alat pengumpul data karena instrumen tersebut sudah baik. Pengujian reliabilitas bertujuan untuk mengetahui konsistensi hasil pengukuran variabel-variabel.

\section{Analisis Regresi Linier Berganda}

Untuk mengetahui atau mengukur pengaruh antara variabel terikat (Y) dengan beberapa variabel bebas (X), maka jenis analisis yang digunakan adalah analisis regresi berganda (Ghozali, 2013). Model persamaan regresi yang digunakan dapat dirumuskan sebagai berikut: $Y=\alpha+\beta_{1} X_{1}+\beta_{2} X_{2}+\beta_{3} X_{3}+$ e.

\section{Analisis Koefisien Determinasi $\left(\mathbf{R}^{2}\right)$}

Koefisien determinasi $\left(\mathrm{R}^{2}\right)$ pada intinya mengukur seberapa jauh kemampuan model dalam menerangkan variasi variabel terikat. Nilai koefisien determinasi adalah antara nol dan satu. Nilai $\left(\mathrm{R}^{2}\right)$ yang kecil berarti kemampuan variabel-variabel bebas (kualitas layanan, harga dan lokasi) dalam menjelaskan variasi variabel terikat (loyalitas konsumen) amat terbatas. Begitu pula sebaliknya, nilai yang mendekati satu berarti variabel-variabel bebas memberikan hampir semua informasi yang di butuhkan untuk memeprediksi variasi variabel terikat.

\section{HASIL DAN PEMBAHAAN}

\section{Statistik Deskriptif Responden}

Dari kuesioner yang telah diisi oleh responden didapat data identitas responden. Penyajian data mengenai identitas responden untuk memberikan gambaran tentang keadaan diri dari para responden.

Berdasarkan status oulet dapat diketahui bahwa Outlet yang berstatus tradisional lebih banyak jika dibandingkan dengan outlet modern dengan jumlah outlet modern 
sebanyak 27 outlet sebesar 27,0\% dari kesluruhan jumlah outlet dan sebanyak 73 outlet sebesar 73,0\% dari kesluruhan jumlah outlet.

Berdasarkan lama berdirinya oulet maka dapat diketahui maka outlet dengan lama berdiri $<2$ tahun sebanyak 21 outlet $(21,0 \%)$, outlet dengan lama berdiri $2-6$ tahun sebanyak 43 orang $(43,0 \%)$, outlet dengan lama berdiri 7 - 11 tahun sebanyak 23 orang $(23,0 \%)$ kemudian outlet dengan lama berdiri < 12 tahun sebanyak 13 orang $(13,0 \%)$.

\section{Pengujian Validitas}

Uji validitas digunakan untuk menguji sejauh mana ketepatan alat pengukur dapat mengungkapkan konsep gejala/kejadian yang diukur. Item kuesioner dinyatakan valid apabila nilai r-hitung > r-tabel (n-2). Hasil pengujian validitas menunjukkan bahwa korelasi antara masing-masing indikator terhadap total skor konstruk dari setiap variabel menunjukkan hasil yang signifikan, dan menunjukkan bahwa $r$ hitung > r tabel. Sehingga dapat disimpulkan bahwa semua item pertanyaan dinyatakan valid.

\section{Pengujian Reliabilitas}

Uji reliabilitas digunakan untuk menguji sejauh mana keandalan suatu alat pengukur untuk dapat digunakan lagi untuk penelitian yang sama. Pengujian reliabilitas dalam penelitian ini adalah dengan menggunakan rumus Alpha. Hasil uji reliabilitas tersebut menunjukkan bahwa semua variabel mempunyai koefisien Alpha yang cukup besar yaitu diatas 0,60 sehingga dapat dikatakan semua konsep pengukur masing-masing variabel dari kuesioner adalah reliabel sehingga untuk selanjutnya item-item pada masing-masing konsep variabel tersebut layak digunakan sebagai alat ukur.

\section{Analisis Persamaan Regresi Linear Berganda}

Model persamaan regresi yang baik adalah yang memenuhi persyaratan asumsi klasik, antara lain semua data berdistribusi normal, model harus bebas dari gejala ultikolinieritas dan terbebas dari heterokedastisitas. Analisis regresi digunakan untuk menguji hipotesis tentang pengaruh secara parsial variabel bebas terhadap variabel terikat dengan hasil persamaan : Y = 1,714 + 0,254 X1 + 0,237 X2 + 0,319 X3

Dari persamaan tersebut dapat dijelaskan bahwa:

a. Variabel strategi selling-in, hubungan distributor dengan outlet dan strategi pelayanan outlet mempunyai arah koefisien yang bertanda negatif terhadap kinerja pemasaran. 
b. Koefisien strategi selling-in memberikan nilai sebesar 0,254 yang berarti bahwa jika strategi selling-in semakin baik dengan asumsi variabel lain tetap maka kinerja pemasaran akan mengalami peningkatan.

c. Koefisien hubungan distributor dengan outlet memberikan nilai sebesar 0,237 yang berarti bahwa jika hubungan distributor dengan outlet semakin kuat dengan asumsi variabel lain tetap maka kinerja pemasaran akan mengalami peningkatan.

d. Koefisien strategi pelayanan outlet memberikan nilai sebesar 0,319 yang berarti bahwa jika strategi pelayanan outlet outlet semakin tinggi dengan asumsi variabel lain tetap maka kinerja pemasaran akan mengalami peningkatan.

\section{Koefisien Determinasi $\left(\mathbf{R}^{2}\right)$}

Koefisien determinasi merupakan besaran yang menunjukkan besarnya variasi variabel dependen yang dapat dijelaskan oleh variabel independennya. Dengan kata lain, koefisien determinasi ini digunakan untuk mengukur seberapa jauh variable-variabel bebas dalam menerangkan variabel terikatnya. Hasil perhitungan regresi dapat diketahui bahwa koefisien determinasi (adjusted R2) yang diperoleh sebesar 0,639. Hal ini berarti 63,9 variasi variabel kinerja pemasaran dapat dijelaskan oleh variabel strategi selling-in, hubungan distributor dengan outlet dan strategi pelayanan outlet sedangkan sisanya sebesar 36,1\% diterangkan oleh variabel lain yang tidak diajukan dalam penelitian ini.

\section{Pembahasan}

Berdasarkan hasil pengujian secara statistik dapat terlihat dengan jelas bahwa secara parsial (individu) semua variabel bebas berpengaruh terhadap variabel terikat. Pengaruh yang diberikan ketiga variabel bebas tersebut bersifat positif artinya semakin tinggi strategi selling-in, hubungan distributor dengan outlet dan strategi pelayanan outlet maka mengakibatkan semakin tinggi pula kinerja pemasaran yang dihasilkan. Hasil tersebut sesuai dengan hipotesis yang diajukan. Hasil penelitian ini juga sesuai dengan hasil penelitian sebelumnya.

\section{Pengaruh Strategi selling-in Terhadap Kinerja pemasaran}

Hasil pengujian hipotesis (H1) telah membuktikan terdapat pengaruh antara strategi selling-in terhadap kinerja pemasaran. Melalui hasil perhitungan yang telah dilakukan diperoleh nilai t hitung sebesar 2,978 dengan taraf signifikansi hasil sebesar 
0,004. Taraf signifikansi tersebut lebih kecil dari 0,05, dengan demikian Ha diterima dan Ho ditolak. Pengujian ini secara statistik membuktikan bahwa strategi selling-in berpengaruh positif terhadap kinerja pemasaran. Hal ini disebabkan adanya aspek-aspek yang berkaitan dengan strategi selling-in yang telah memberikan dampak positif terhadap kinerja pemasaran CV Rajeev Indo Soul Elmo Kabupaten Malang. Aspek-aspek strategi selling-in tersebut diantaranya adalah: ketersediaan produk, keragaman produk dan kemenarikan produk. Artinya bahwa ada pengaruh antara variabel strategi selling-in terhadap kinerja pemasaran CV Rajeev Indo Soul Elmo Kabupaten Malang. Hasil ini mendukung penelitian sebelumnya oleh Wiryawan (2008); Arif (2004); Sunaryo (2002) dengan hasil analisis yaitu strategi selling-in memiliki pengaruh terhadap kinerja pemasaran

\section{Pengaruh Hubungan Distributor Dengan Outlet Terhadap Kinerja Pemasaran}

Hasil pengujian hipotesis $(\mathrm{H} 2)$ telah membuktikan terdapat pengaruh antara hubungan distributor dengan outlet terhadap kinerja pemasaran. Melalui hasil perhitungan yang telah dilakukan didapat nilai t hitung sebesar 2,957 dengan taraf signifikansi hitung sebesar 0,004. Taraf signifikansi tersebut lebih kecil dari 0,05, yang berarti bahwa hipotesis dalam penelitian ini menolak Ho dan menerima Ha, Pengujian ini secara statistik membuktikan bahwa hubungan distributor dengan outlet berpengaruh positif terhadap kinerja pemasaran. Artinya bahwa ada pengaruh antara variabel hubungan distributor dengan outlet terhadap kinerja pemasaran CV Rajeev Indo Soul Elmo Kabupaten Malang. Hal ini disebabkan adanya aspek-aspek yang berkaitan dengan hubungan distributor dengan outlet yang telah memberikan dampak positif terhadap kinerja pemasaran CV Rajeev Indo Soul Elmo Kabupaten Malang. Aspek-aspek hubungan distributor dengan outlet tersebut diantaranya adalah: kepercayaan, intensitas komunikasi dan kepuasan. Hasil ini mendukung penelitian sebelumnya Arif (2004) yaitu adanya pengaruh secara signifikan antara hubungan distributor dengan outlet terhadap kinerja pemasaran.

\section{Pengaruh Strategi Pelayanan outlet Terhadap Kinerja pemasaran}

Hasil pengujian hipotesis $(\mathrm{H} 3)$ telah membuktikan terdapat pengaruh antara strategi pelayanan outlet terhadap kinerja pemasaran. Melalui hasil perhitungan yang telah dilakukan diperoleh nilai t hitung sebesar 2,805 dengan taraf signifikansi hasil 
sebesar 0,006. Taraf signifikansi tersebut lebih kecil dari 0,05, yang berarti bahwa hipotesis dalam penelitian ini menerima Ha dan menolak Ho. Pengujian ini secara statistik bahwa strategi pelayanan outlet berpengaruh positif terhadap kinerja pemasaran. Artinya bahwa ada pengaruh antara variabel strategi pelayanan outlet terhadap kinerja pemasaran CV Rajeev Indo Soul Elmo Kabupaten Malang. Hal ini disebabkan adanya aspek-aspek yang berkaitan dengan strategi pelayanan outlet yang telah memberikan dampak positif terhadap kinerja pemasaran CV Rajeev Indo Soul Elmo Kabupaten Malang. Aspek-aspek strategi pelayanan outlet tersebut diantaranya adalah: kunjungan, kebijakan return dan periode bayar. Hasil ini mendukung penelitian sebelumnya oleh Arif (2004) dan Homburg (2002) yang menyatakan bahwa strategi pelayanan outlet berpengaruh positif dan signifikan terhadap kinerja pemasaran.

\section{Pengaruh Strategi selling-in, Hubungan distributor dengan outlet dan Strategi pelayanan outlet Terhadap Kinerja pemasaran.}

Hasil pengujian hipotesis (H4) telah membuktikan terdapat pengaruh antara strategi selling-in, hubungan distributor dengan outlet, strategi pelayanan outlet terhadap kinerja pemasaran. Melalui hasil perhitungan yang telah dilakukan diperoleh nilai $\mathrm{F}$ hitung sebesar 32,162 dengan taraf signifikansi hasil sebesar 0,004. Taraf signifikansi tersebut lebih kecil dari 0,05, yang berarti bahwa hipotesis dalam penelitian ini menerima Ha dan menolak Ho. Pengujian ini secara statistik bahwa pengaruh antara strategi sellingin, hubungan distributor dengan outlet, strategi pelayanan outlet berpengaruh positif terhadap kinerja pemasaran. Artinya bahwa ada pengaruh antara variabel secara simultan terhadap kinerja pemasaran CV Rajeev Indo Soul Elmo Kabupaten Malang. Hal ini disebabkan adanya aspek-aspek yang berkaitan dengan kinerja pemasaran CV Rajeev Indo Soul Elmo Kabupaten Malang.

\section{KESIMPULAN, KETERBATASAN DAN SARAN}

\section{Kesimpulan}

Dari pembahasan yang telah diuraikan, maka dapat ditarik kesimpulan sebagai berikut:

1) Hasil pengujian hipotesis (H1) telah membuktikan terdapat pengaruh antara strategi selling-in terhadap kinerja pemasaran. Melalui hasil perhitungan yang telah dilakukan diperoleh nilai t hitung sebesar 2,978 dengan taraf signifikansi hasil sebesar 0,004. Taraf signifikansi tersebut lebih kecil dari 0,05, dengan demikian Ha diterima 
dan Ho ditolak. Pengujian ini secara statistik membuktikan bahwa strategi selling-in berpengaruh positif terhadap kinerja pemasaran.

2) Hasil pengujian hipotesis (H2) telah membuktikan terdapat pengaruh antara hubungan distributor dengan outlet terhadap kinerja pemasaran. Melalui hasil perhitungan yang telah dilakukan didapat nilai t hitung sebesar 2,957 dengan taraf signifikansi hitung sebesar 0,004. Taraf signifikansi tersebut lebih kecil dari 0,05, yang berarti bahwa hipotesis dalam penelitian ini menolak Ho dan menerima Ha, Pengujian ini secara statistik membuktikan bahwa hubungan distributor dengan outlet berpengaruh positif terhadap kinerja pemasaran.

3) Hasil pengujian hipotesis (H3) telah membuktikan terdapat pengaruh antara strategi pelayanan outlet terhadap kinerja pemasaran. Melalui hasil perhitungan yang telah dilakukan diperoleh nilai t hitung sebesar 2,805 dengan taraf signifikansi hasil sebesar 0,006. Taraf signifikansi tersebut lebih kecil dari 0,05, yang berarti bahwa hipotesis dalam penelitian ini menerima Ha dan menolak Ho. Pengujian ini secara statistik bahwa strategi pelayanan outlet berpengaruh positif terhadap kinerja pemasaran.

4) Hasil pengujian hipotesis (H4) telah membuktikan terdapat pengaruh antara strategi selling-in, hubungan distributor dengan outlet, strategi pelayanan outlet terhadap kinerja pemasaran. Melalui hasil perhitungan yang telah dilakukan diperoleh nilai $\mathrm{F}$ hitung sebesar 32,162 dengan taraf signifikansi hasil sebesar 0,004. Taraf signifikansi tersebut lebih kecil dari 0,05, yang berarti bahwa hipotesis dalam penelitian ini menerima Ha dan menolak Ho. Pengujian ini secara statistik bahwa pengaruh antara strategi selling-in, hubungan distributor dengan outlet, strategi pelayanan outlet berpengaruh positif terhadap kinerja pemasaran.

\section{Keterbatasan Penelitian}

Keterbatasan penelitian ini, menyangkut keterbatasan teoritik dan operasional penelitian. Secara teoritik, penelitian ini masih sangat terbatas pada jumlah variabel yang dilibatkan. Secara operasional, yakni saat pencacahan data di lapangan memang mengalami kendala, utamanya kendala luang waktu yang diberikan responden yang dirasa terbatas, serta tingkat pemahaman responden atas setiap pertanyaan yang diajukan dalam kuesioner. 


\section{Saran}

Berdasarkan kesimpulan di atas, saran yang diberikan sebagai berikut:

1. Selling-in merupakan kegiatan distribusi yang diarahkan pada upaya untuk melakukan penjualan pada semua pedagang perantara untuk mempermudah pencapaian suatu tingkat market coverage yang optimal dengan menggunakan perantara outlet untuk menjangkau konsumen akhir. Keberhasilan dari kinerja selling ditandai dengan kelengkapan barang atau produk yang ditawarkan, tingkat pelayanan yang baik kepada konsumen serta tingkat persediaan produk yang memadai pada outlet. Kondisi ini dapat dicapai dengan pantauan yang rutin terhadap kelengkapan dan ketersediaan barang di outlet sehingga konsumen selalu mendapatkan segala sesuatu yang diinginkan.

2. Strategi pelayanan yang baik perlu dilakukan oleh perusahaan melalui sistem kunjungan yang baik dan rutin dimana hal ini akan sangat bermanfaat dalam upaya mengidentifikasi kebutuhan pelanggan. Kondisi di atas dapat dicapai dengan mempertinggi frekuensi kunjungan ke outlet sehingga komunikasi dengan outlet dapat terjaga dengan baik.

3. Hubungan distributor dengan outlet perlu dijalin dengan baik. Hal ini dapat di lakukan dengan memperhatikan beberapa faktor seperti intensitas kontak atau komunikasi yang baik antara ditributor dengan outlet-outletnya. Selain itu adanya kemauan untuk mempertahankan hubungan yang telah terjalin selama mungkin agar mendapatkan kedekatan secara institusi maupun secara personal.

4. Diharapkan, dalam penelitian mendatang perlu ditambah variabel, tidak saja variabel yang sifatnya internal perusahaan, tetapi juga variabel eksternal perusahaan seperti misalnya variabel kebijakan pemerintah, agar diperoleh temuan yang makin lengkap dan lebih up to date dengan perkembangan dunia bisnis pada saat ini.

\section{DAFTAR PUSTAKA}

Adikusumo. (2003). Analisis Pengaruh Kualitas Hubungan Bisnis Antara Tenaga Penjualan dan Retailer Terhadap Efektifitas Penjualan, Jurnal Sains Pemasaran Indonesia, Vol II, No 3, p.247-264. 
Arif. (2004). Analisis Kinerja Distribusi Selling-In Untuk Meningkatkan Kinerja Pemasaran (studi kasus pada supplier swalayan Sri Ratu Pemuda Semarang. Jurnal Sains Pemasaran Indonesia, Volume II, No 1, p 55-70.

Augusty, Ferdinand, 2006. Metode Penelitian Manajemen: Pedoman Penelitian Untuk Penulisan Skripsi, Tesis dan Disertasi Ilmu Manajemen. Badan Penerbit Universitas Diponegoro. Semarang

Diah, Yoestini. (2003). Studi Mengenai PengembanganHubungan Jangka Panjang Perusahaan dan Penyalur, Jurnal Sains Pemasaran Indonesia, Vol II, No 1, p 6784.

Garbarino, Johnson (1999). The Different Roles of Satisfaction, Trust, and Commitment in Customer Relationships, Journal of Marketing, Vol 63, April 1999.

Gebauer, Gustafsson, Witell (2011). Competitiv Advantage Trough Service Differentiation by Manufacturing Companies, Of Page 11.

Homburg. (2002). Service Orientation of a Retailers Bussines Strategy : Dimention, Antecedents, and Performance Outcomes, Jounal of Marketing Voll 66 (Oktober), p86-101.

Kotler, Philip. 2002. Manajemen Pemasaran, Analisa perencanaan, Implementasi dan control, Edisi Kesembilan, Jilid 1 dan jilid 2, Jakarta.

Kotler, Philip. 2007. Manajemen Pemasaran, Analisis Perencanaan, Pengendalian,. Prentice Hall, Edisi Bahasa Indonesia, Jakarta: PT. Indeks

Kotler, Philip; Armstrong, Garry, 2008. Prinsip-prinsip Pemasaran, Jilid 1,. Erlangga, Jakarta

Laksana, 2008, Manajemen Pemasaran, Graha Ilmu, Yogyakarta.

Philip Kotler \& Kevin Lane Keller, 2009, Manajemen pemasaran, Edisi 13 Jilid. 1. Jakarta.

Prasetyo, B., dkk. (2011). Metode Penelitian Kuantitatif, Jakarta: Rajawali Pers

Qomariah, Nurul. 2016. Marketing Adactive Strategy. Jember. Cahaya Ilmu.

Rangkuti, Freddy. (2003). Riset Pemasaran. PT. Gramedia Pustaka Utama, Jakarta.

Sugiyono. (2012). Metode Penelitian Kuantitatif Kualitatif dan RD. Bandung: Alfabeta.

Sugiyono. 2002. Metode Penelitian Administrasi. Bandung : CV Alfabeta.

Sunaryo. (2002). Dinamika Startegi Pelayanan Outlet dan Kinerja Pemasaran, Journal Sains Pemasaran Indonesia, Vol 1, No 1, Mei p41-56. 
Susanto, Faiz (2006). Analisis faktor faktor yang mempengaruhi omitmen penyalur sebagai upaya meningkatkan hubungan jangka panjangdengan distributor (studi kasus pada para penyalur PT. Merapi Utama Pharma Cabang Semarang, Jurnal Bisnis Strategi Program Magister Manajemen Universitas Diponegoro, Vol 16, No 2, p 21-33.

Tjiptono. (2002). Strategi Pemasaran. Andi, Yogyakarta

Ujang Suwarman, 2004, “Perilaku Konsumen Teori dan Penerapannya dalam Pemasaran, Penerbit: PT Ghalia Indonesia, Bogor.

Wiryawan, (2008). Analisis Faktor Faktor yang Menentukan Kinerja Selling-In dan Pengaruhnya Terhadap Kinerja Pemasaran. 